$14^{\text {th }}$ Conf. Agric. Develop. Res., Fac. of Agric., Ain Shams Univ., March, 2019, Cairo, Egypt

Special Issue, 27(1), 231 - 238, 2019

Website: http://strategy-plan.asu.edu.eg/AUJASCI/

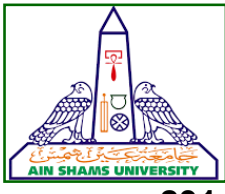

\title{
COMPARATIVE STUDY OF DIFFERENT VACCINATION ROUTES AGAINST NEWCASTLE DISEASE IN LAYER CHICKENS
}

\author{
Samar S. El-Masry ${ }^{1}$, Nasr-Eldin M.A. ${ }^{2}$, Abeer A. Faiesal ${ }^{3}$ \\ and Othman B.A. ${ }^{1}$
}

1. Agric. Microbiology Dept., Fac. of Agric., Ain Shams Univ., P.O. Box 68, Hadayek Shobra 11241, Cairo, Egypt

2. Botany Dept., Fac. of Science, Benha Univ., Kalyobya, Egypt.

3. Basic and Applied Agric. Sciences Dept., Higher Institute for Agric. Co-Operation, Cairo, Egypt.

\section{*Corresponding author: samar_sayed@agr.asu.edu.eg}

\section{ABSTRACT}

In the present study, a trail to evaluate of Newcastle Disease (ND) antibodies levels after different vaccination programs was conducted on layer chickens. A total of 200 one day-old layer chicks (White Lohmann) were divided into five groups $A$, $B, C, D$ and $E$. Birds in groups $A, B$ and $C$ were vaccinated with live vaccine by intraocular, intranasal and drinking water methods, respectively. On the other hand, groups D and E were kept as unvaccinated control groups. Vaccination performed at days 5,18 and 28 by different routes for mentioned groups. Hemagglutination inhibition $(\mathrm{HI})$ and enzyme-linked immunosorbent assay (ELISA) methods were used for assessment of antibodies titer at days 15, 25, 37 and 45. Results of $\mathrm{HI}$ and ELISA tests indicated that, the intranasal and the intraocular method have highest antibodies titers compared with the drinking water method. In this study, maternally derived antibodies specific to Newcastle Disease Virus (NDV) (IgY) were extracted by dextran sulfate method from collected eggs of vaccinated laying chickens. Antibodies specific to NDV ( $\lg Y)$ were detected in the egg yolk using $\mathrm{HI}$ test. Data revealed that antibodies specific to NDV $(\lg Y)$ were presented in high titers that confer protection during early weeks of life for hatching chicks. Data concluded that extraction of maternally derived specific antibodies from egg yolk will facilitate accurate monitoring of ND vaccination programmes.
Key Words: Vaccination routes, ND, Layer Chickens, Antibody titer, ELISA, HI test.

\section{INTRODUCTION}

Newcastle disease (ND) is one of the most infectious viral diseases of poultry. Newcastle disease (ND) is a disease of chickens, turkeys, pigeons and other avian species caused by a filterable virus known as Newcastle disease virus (NDV). Morbidity and mortality in susceptible birds reaching up to $90-100 \%$ in the severe forms of the disease in unvaccinated birds. The infection was characterized by respiratory, digestive and nervous signs. The total average losses in poultry due to ND are presently estimated to be $40-60 \%$ in spite of vaccination and medication schedules. (Dortmans et al 2012, Al-Habeeb et al 2013 and Ashraf \& Shah, 2014).

Vaccination of broiler chicken flocks against ND usually carried out by non-virulent live virus administered by spray or eye-drop, or via drinking water. The various ways of administration usually produce considerable variation in the antibody responses of vaccinated birds, which causes variation in the levels of protection of broilers against disease outbreaks (Senne et al 2004). Immune responses to ND vaccines are influenced by routes (ocular, injection, drinking water, aerosol or nasal) of vaccination. Eye drop vaccination stimulates Harderian gland to produce local antibodies (Shabbir et al 2013). Vaccines given through mucosal surfaces (eye drop and nasal) generate mucosal immune response. Also vaccines given through mucosal 
routes are more effective against viruses which entering in the body through mucosal surfaces, such as NDV (Calnek et al 1997).

Very young chicks are susceptible to many pathogens during the first few weeks of age because their immune system is not fully developed. The maternal antibodies are the primary means of antigen-specific protection (Hamal et al 2006).

Haemagglutination Inhibition $(\mathrm{HI})$ test is still the most widely used serological method for measuring NDV antibodies in chicken sera and considered the gold standard test for this disease (OIE, 2012). Alternatives to $\mathrm{HI}$ test, Enzyme Linked Immune Sorbent Assays (ELISA) were used to measure NDV antibodies in chicken and proved to be well correlated to $\mathrm{HI}$ test for evaluation of NDV antibodies in poultry serum (Brown et al 1990).

Chickens that survive infection with virulent Newcastle disease virus develop a long lasting immunity to further infection with Newcastle disease virus. The basis of this immunity is circulating antibodies, secretory antibody (producing mucosal immunity) and cell mediated immunity (Grimes, 2002). Hens with antibodies to NDV will pass these on to their progeny via the egg yolk. The populations of $\lg Y$ are transported according to their concentration in the maternal serum and thus levels of antibody in day- old chicks will be directly related to titers in the parent (Alexander, 2003). Maternal antibodies protect chicks with week immunity for three to four weeks after hatching (Murphy et al 1999).

Therefore, the current investigation was undertaken to make a comparative study between different routes of vaccination to protect birds against NDV and also to determine whether there was any effective parental immunity (IgY antibodies) in birds from immunized flocks.

\section{MATERIALS AND METHODS}

\section{Ethical approval}

All institutional instructions and guidelines for the rearing and handling animals for research and experimental design have been followed according to the legally approved protocol [AHRI (29) 23/11/2017] of the Animal Health and Research Institute (AHRI), Giza, Egypt.

\section{Experimental chicks}

A total of 200 one day-old layer chicks (White Lohmann) were hatched from eggs of local flocks and were procured from local commercial hatchery. The chicks were reared under standard managemental and biosecurity conditions at local farm. The chicks were provided feed and water ad libitum.

\section{Source of Vaccine}

La Sota vaccine was obtained from Vertebrates' Viruses' Lab, Dep. of Agricultural Microbiology, Fac. of Agriculture, Ain Sham Univ., Cairo, Egypt. Each dose was found to be with $10^{6.5} \mathrm{Em}$ bryo infective dose (EID 50) / $\mathrm{ml}$ following titration of the vaccine.

\section{Source of Newcastle disease virus challenge}

Newcastle disease virus isolate was procured from vertebrates' viruses' lab, Dep. of Agricultural Microbiology, Fac. of agriculture, Ain sham Univ., Cairo, Egypt. It was isolated from infected chicken and characterized as a velogenic NDV isolate by El-Masry et al (2016) and it had been passaged once through 10 day old chicken embryonated eggs and stored at $-20^{\circ} \mathrm{C}$ until used. Embryo infective dose (EID ${ }_{50}$ ) was determined by Read and Muench, 1938.

\section{Experimental design}

The chicks were randomly divided into five major groups namely A, B, C D and E, each group contained 40 chicks. The birds were vaccinated on day 5,18 and 28 according to the following schedule:

Group A: Birds were vaccinated by intraocular instillation with one drop of 1:10 dilution in Phosphate buffer saline (PBS) of the vaccine in each bird.

Group B: Birds were vaccinated by intranasal instillation with one drop of 1:10 dilution of the vaccine in each bird.

Group C: Birds were vaccinated with 1:100 dilution of the vaccine in drinking water $(3 \mathrm{ml}$ vaccine mixed with $297 \mathrm{ml}$ water).

Group D: Birds were infected with NDV and not vaccinated.

Group E: Birds were inoculated intramuscularly with $0.1 \mathrm{ml}$ of phosphate buffered saline (PBS) as placebo (No vaccination and No infection).

On day 38 , birds of groups $A, B, C$ and $D$ were challenged intramuscularly with NDV inoculums at dose rate of $0.1 \mathrm{ml} /$ bird $\left(10^{6.7}\right.$ EID50/ $\left.0.1 \mathrm{ml}\right)$. Birds 
were observed for 10 days post challenge and mortality in birds of all groups was recorded.

\section{Collection of samples}

The present study was carried out at Animal Health Research Institute, Dokki, and Giza, Egypt. Blood samples were collected by vein wing method from 5 randomly selected birds of each group on days, 15, 25, 37 and 45. The blood serum was separated by centrifugation at $3000 \mathrm{rpm}$ for 10 $\min$. Separated sera were stored at $-20^{\circ} \mathrm{C}$ before tested for NDV antibody titers.

\section{Determination of antibody titers against NDV}

Phosphate buffer saline solution $(\mathrm{pH} 7.2)$ was used in $\mathrm{HI}$ and ELISA tests, Erythrocytes from 6 weeks old Specific-Pathogenic-Free (SPF) chicken blood were washed and their 1 percent solution was used in $\mathrm{HI}$ tests. The $\mathrm{HI}$ tests were conducted according to the protocol described by the Office International Epizootics (OIE, 2012) and the specific monoclonal antiserum against NDV was supplied kindly from Veterinary Serum and Vaccine Research Institute (VSVRI), Abbasia, Cairo, Egypt.

ELISA technique was done according to kit instruction (Newcastle disease virus Antibody Test Kit, FlockChek; IDEXX Inc,USA) .

\section{Collection of egg samples from vaccinated Lay- ing chickens}

Chickens that did not record any infection signs and mortality percentage from each group were kept for collecting egg samples. Laying white Lohmann chickens aging 4 months had given booster dose of La Sota vaccine $\left(10^{6.5}\right.$ Embryo infective dose (EID 50)/ml). Birds were vaccinated by intranasal instillation with one drop of 1:10 dilution of the vaccine in each bird. Egg samples from laying white Lohmann chickens aging 5 months were collected and placed at $4^{\circ} \mathrm{C}$ untill using.

\section{Extraction of NDV (IgY) from Egg Yolk}

Extraction was carried out by the protocol mentioned by Jensenius et al (1981). Extracted antibodies were assayed using $\mathrm{HI}$ test as described by OIE, 2012

\section{Statistical analysis}

The SPSS statistic software version 22.0 used for analysis of data, and One-way Analysis of Vari- ances along with Duncan post hoc test used for evaluation of data (Coakes et al 2006).

\section{RESULTS AND DISCUSSION}

\section{Determination of Antibody titers against NDV}

Newcastle disease continuing to be a major danger to poultry industry in spite of using different types of vaccination worldwide. One way of controlling this problem is improving efficiency of vaccination by using different routes of immunization. In the current study, three routes (intraocular, intranasal and drinking water) of vaccination against NDV were used on 5, 18 and 28 day of age. Data in Tables and Figures 1 and 2 stated that antibodies titers were produced from the three method of vaccination (intraocular, intranasal and drinking water).

Results of $\mathrm{HI}$ antibody test in Table and Figure 1 indicated that there was no significant difference between groups on day 15, although in Table 2, antibody titration by ELISA test indicated that there was significant difference between groups .Result also showed that, at the day 25 the antibodies raised significantly in group $A, B$ and $C$, compared with the healthy birds in group $E$.

Table 1. Antibody titers against the Newcastle disease by $\mathrm{HI}$ test

\begin{tabular}{|c|c|c|c|c|}
\hline \multirow{2}{*}{ Groups } & \multicolumn{3}{|c|}{ Titer of NDV antibodies by HI test } \\
\cline { 2 - 5 } & Day 15 & Day 25 & Day 37 & Day 42 \\
\hline (A) & $2.60 \pm 0.17^{\mathrm{a}}$ & $3.80 \pm 0.14^{\mathrm{b}}$ & $2.54 \pm 0.14^{\mathrm{a}}$ & $5.00 \pm 0.19^{\mathrm{b}}$ \\
(B) & $2.80 \pm 0.14^{\mathrm{a}}$ & $4.94 \pm 0.11^{\mathrm{a}}$ & $2.91 \pm 0.18^{\mathrm{a}}$ & $6.22 \pm 0.13^{\mathrm{a}}$ \\
(C) & $2.43 \pm 0.19^{\mathrm{a}}$ & $3.25 \pm 0.18^{\mathrm{b}}$ & $2.34 \pm 0.12^{\mathrm{a}}$ & $4.09 \pm 0.11^{\mathrm{c}}$ \\
(D) & $2.00 \pm 0.20^{\mathrm{a}}$ & $2.10 \pm 0.11^{\mathrm{c}}$ & $3.98 \pm 0.15^{\mathrm{b}}$ & $3.00 \pm 0.20^{\mathrm{d}}$ \\
(E) & $1.10 \pm 0.13^{\mathrm{b}}$ & $1.15 \pm 0.16^{\mathrm{d}}$ & $1.33 \pm 0.21^{\mathrm{c}}$ & $1.68 \pm 0.18^{\mathrm{e}}$ \\
\hline
\end{tabular}

Group $A=$ Birds were vaccinated by intraocular method.

Group $B=$ Birds were vaccinated by intranasal method.

Group $C=$ Birds were vaccinated by drinking water method.

Group $D=$ Birds were infected with NDV and No vaccinated

Group $\mathrm{E}=$ No infection and No vaccination.

-The results are as $\log _{2}$ antibody titers (geometric mean \pm Standard Error (S.E) ).

${ }^{*}$ Different alphabetic indicate significant difference between columns $(p<0.05)$.

Data also showed a gradual rise in antibody titer by day progression. The obtained data were in line with what stated by Nachimuthu et al (1982), 
Jayawardane and Spradbrow (1995) and Sun et al (1997). Results are also agreement with Tizzara (1996) who reported that gastric secretions provided a non-specific barrier against invaders and destroyed them. Thus, some of the viral vaccines given through oral route got denatured resulting in reduced antibody titer in group $C$. Decrease in antibodies titers were observed in groups $A, B$ and $C$ on $37^{\text {th }}$ day of experiment ( 7 days post challenge), as shown in Tables 1 and 2 . These observations are in line with Tizzard (1996) who reported a decrease in antibody titers due to neutralization of virus with circulating antibodies. But in group $D, a$ sharp rise in antibody titer was observed on $37^{\text {th }}$ day. Tizzard (1996) also reported a rise in antibodies titers due to activation of immune system against challenge with NDV. On the other hand, a sharp rise in antibody titer was also detected in groups A, B and C on day 45 (15 days post challenge). The antibody titer was highest in group $B$ (Intranasal method) then groups A (Intraocular method) and the least titration was in group $C$ (Drinking water) $(\mathrm{p}<0.05)$ in $\mathrm{HI}$ and ELISA test, this agreed with what mentioned by Rehmani (1996). Similarly, Manzoor (1999) observed that in vaccinated birds challenged virus was neutralized by antibodies and the immune system was enhanced resulting in increase in antibody titer.
Immune response in drinking water route of vaccination depends on the strain of vaccine. It was demonstrated that the F strain and La Sota strain produce $85.90 \%$ protection against challenge whereas the Mukteswar strain only provide 45\% protection. Environmental conditions and age of birds affects the serologic response to drinking water method and to prevent from vaccine inactivation the water containing vaccine should be drunk as soon as possible (Rehmani, 1996).

Table 2. Antibody titers against the Newcastle disease by ELISA test

\begin{tabular}{|c|c|c|c|c|}
\hline \multirow{2}{*}{ Groups } & \multicolumn{4}{|c|}{ Titer of NDV antibodies by ELISA test } \\
\cline { 2 - 5 } & Day 15 & Day 25 & Day 37 & Day 42 \\
\hline (A) & $3.73 \pm 0.23^{\mathrm{b}} \mathrm{y}$ & $4.90 \pm 0.18^{\mathrm{b}}$ & $3.36 \pm 0.26^{\mathrm{a}}$ & $6.06 \pm 0.26^{\mathrm{b}}$ \\
(B) & $4.00 \pm 0.19^{\mathrm{a}}$ & $5.86 \pm 0.23^{\mathrm{a}}$ & $3.20 \pm 0.21^{\mathrm{a}}$ & $7.60 \pm 0.22^{\mathrm{a}}$ \\
(C) & $2.80 \pm 0.20^{\mathrm{c}}$ & $3.70 \pm 0.21^{\mathrm{c}}$ & $3.00 \pm 0.25^{\mathrm{a}}$ & $5.40 \pm 0.24^{\mathrm{c}}$ \\
(D) & $2.10 \pm 0.22^{\mathrm{c}}$ & $2.23 \pm 0.24^{\mathrm{d}}$ & $4.50 \pm 0.28^{\mathrm{b}}$ & $4.00 \pm 0.18^{\mathrm{d}}$ \\
(E) & $1.22 \pm 0.20^{\mathrm{d}}$ & $1.34 \pm 0.22^{\mathrm{e}}$ & $1.26 \pm 0.20^{\mathrm{c}}$ & $1.37 \pm 0.24^{\mathrm{e}}$ \\
\hline
\end{tabular}

Group $A=$ Birds were vaccinated by intraocular method. Group $B=$ Birds were vaccinated by intranasal method Group $\mathrm{C}=$ Birds were vaccinated by drinking water method. Group $D=$ Birds were infected with NDV and No vaccinated Group $\mathrm{E}=$ No infection and No vaccination.

The results are as $\log _{10}$ antibody titers (geometric mean \pm S.E.) *Different alphabetic indicate significant difference between columns $(\mathrm{P}<0.05)$.

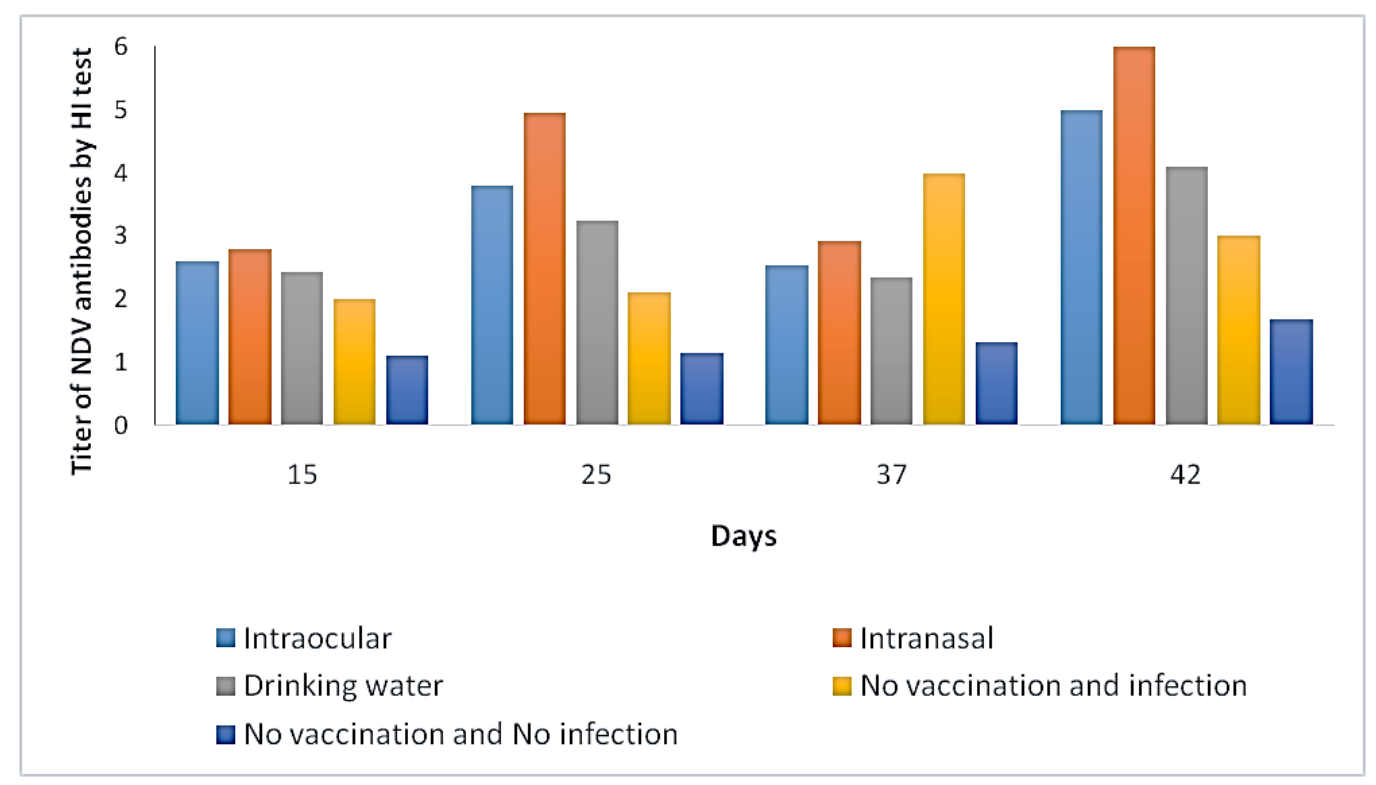

Fig. 1. Antibody titers against the Newcastle disease by HI test 


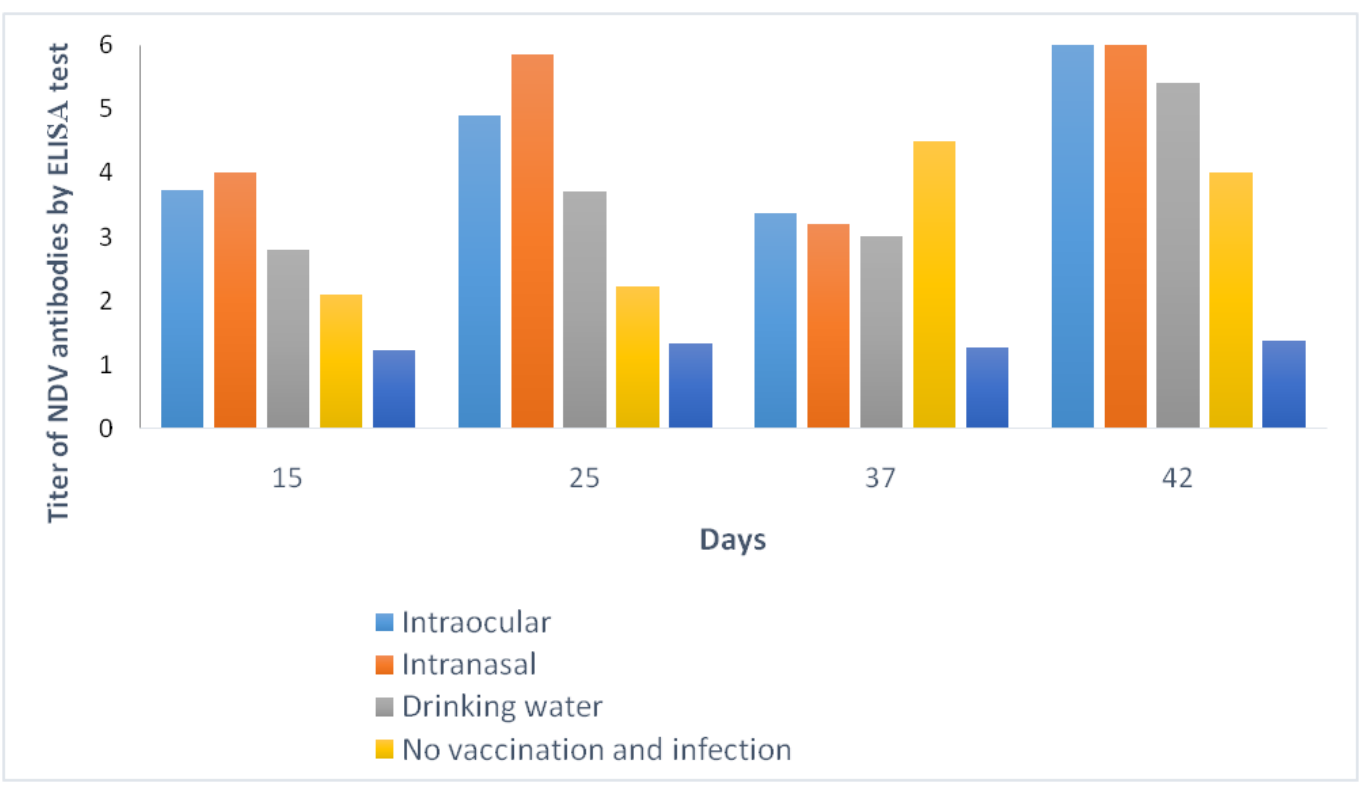

Fig. 2. Antibody titers against the Newcastle disease by by ELISA test

\section{Comparison between different routes of vac- cination based on challenge of NDV}

Mortality within 4-6 days due to challenge with virulent NDV is detailed in Table 3, data revealed that, in group A which vaccinated intraoculary, only 7 birds died from total of 40 birds an overall mortality was 17.5 percent. In group B which vaccinated intranasaly, 3 of the vaccinated birds died and giving a mortality of 7.5 per cent. In group $\mathrm{C}$ which given the vaccine with drinking water, a total of 15 birds died with an overall mortality of 37.5 per cent . Data indicated that group A, B and C gained 82.5, 92.5 and $62.5 \%$ protection respectively. Obtained results were similar to what found by Winterfield et al (1969). All the control birds of group D ( unvaccinated and infected with NDV), died after 4-6 days post challenge with virulent NDV. On the other hand, all birds in group $E$ (no vaccination and no infection) did not record any mortality percentage.

Data in Table 3 also show that the birds on group $D$ which had not been vaccinated could not survive post of the challenge with virulent NDV. The birds which challenged with virulent NDV , showed general depression,closing of eyes and paralysis after 3 to 4 days post challeng, following by death. The postmortem examination of dead birds after challenge showed haemorrhages in the proventriculus, Spleen enlarged and in few cases the lung were hyperaemic.
Comparison between the three methods of vaccination showed that the drinking water route was the poorest. It may be because antigens administered by this route are sometimes lost before ingestion or partly to wholly digested in the alimentary canal, on the other hand, the intranasal and intraocular route, are more efficient methods of vaccination, respectively .

Table 3. Mortality percentage of birds of different groups after infection

\begin{tabular}{|cccccc|}
\hline Groups & $\begin{array}{c}\text { Total } \\
\text { birds }\end{array}$ & $\begin{array}{c}\text { Live } \\
\text { birds }\end{array}$ & $\begin{array}{c}\text { Dead } \\
\text { birds }\end{array}$ & $\begin{array}{c}\text { Mortality } \\
\%\end{array}$ & $\begin{array}{c}\text { Protection } \\
\%\end{array}$ \\
\hline A & 40 & 33 & 7 & 17.5 & 82.5 \\
B & 40 & 37 & 3 & 7.5 & 92.5 \\
C & 40 & 25 & 15 & 37.5 & 62.5 \\
D & 40 & 0.0 & 40 & 100 & 0.0 \\
E & 40 & 40 & 0.0 & 0.0 & $\begin{array}{c}\text { Not chal- } \\
\text { lenged }\end{array}$ \\
\hline
\end{tabular}

Assaying of NDV antibodies in the egg yolk by HI test

In this study the egg yolk antibodies were extracted by the dextran sulphate method according to Jensenius et al (1981) whom they 
demonstrated that the $\lg Y$ preparation with dextran sulphate is very effective, quick and simple to perform. This procedure does not give completely pure $\lg Y$ but the preparation is free from other classes of immunoglobulin because of their absence from yolk as stated by Hamal et al.(2006) who reported that $\lg Y$ is present predominantly in the egg yolk, whereas $\lg \mathrm{A}$ and $\lg \mathrm{M}$ are present in the egg white.

Data in Table 4 represent the $\mathrm{HI}$ values that used for assaying the presence or absence of NDV antibodies in the egg yolk in collected egg samples from group A, B, C and E. Data revealed that the NDV antibodies were found in the egg yolk extracts (the positive results in group A,B and C), it indicates transfer of maternal antibodies from hen 's serum to the egg yolk and specificity of the antibodies to NDV. Data also showed high titers of NDV specific antibodies that was measured in eggs of immunized hens collected during the first month after the last dose of vaccination (five months old). This booster dose in mothers developed high titers of NDV specific antibodies that peak at about three to four weeks after vaccination and these results substantiate the study reported by Alexander (2003). This suggests the importance of revaccination of laying hens every four months as reported by Murphy et al (1999). Earlier studies have reported that serologic response to primary vaccination with different strains of ND vaccines were similar but after second booster vaccination some strains produce better antibody response Roy et al (1998).

Therefore, extraction of maternally derived NDV antibodies will facilitate accurate monitoring of ND vaccination programmes. Hamal et al (2006) reported that the $\lg Y$ levels were found to be a direct indicator of maternal antibody transfer to the chicks' circulation.Although maternal antibodies provide passive immunity in young chicks for a few weeks after hatching and considered to be protective, they also interfere with the chick's active response to vaccination. Maternal antibody interferers with active immunization, this was reported by Stone et al (1979) who reported that maternal antibody neutralizes the introduced vaccine antigen rendering the vaccine ineffective and immune response was nil at high titer of maternal antibody and thus, taken into consideration during primary vaccination. They also reported that $\lg Y$ is more highly concentrated in yolk than it is in serum.
Table 4. Presence of NDV antibodies in the egg yolk by $\mathrm{HI}$ test

\begin{tabular}{|c|c|c|}
\hline Groups & $\begin{array}{c}\text { presence of NDV } \\
\text { antibodies }\end{array}$ & $\begin{array}{c}\text { titer of NDV } \\
\text { antibodies }\end{array}$ \\
\hline A & + & 256 \\
B & + & 512 \\
C & + & 64 \\
D & ND* $^{*}$ & ND* $^{*}$ \\
E & & \\
\hline
\end{tabular}

${ }^{*} \mathrm{ND}=$ Not detected because all birds in this group were died due to infection with NDV.

On conclusion, This study concluded that live vaccines administered by the intranasal and intracular routes gave a better immunogenic response than other routes. This may be because the respiratory mucosa was easily penetrable by virus particles .Similar may be the case when vaccine was administered through the intraocular route. The virus then enters the lymphatics and the lymph nodes and thus causes a stimulation of the antibody forming mechanism of the bird. In this study also maternally derived antibodies present in the egg yolk specific to NDV were presented in high titers that confer protection during early weeks of life of hatching chicks. Extraction of maternally derived specific antibodies from egg yolk will facilitate accurate monitoring of ND vaccination programmes.

\section{REFERENCES}

Alexander, D.J. 2003. Newcastle disease In: Y. M. Saif., J.R. Barnes, A.M. Glisson, L.R. McDougald Fadly and D.E. Swayn (Eds.), Diseases of Poultry (11 ${ }^{\text {th }}$ Ed.). pp. 101-119. lowa State University Press: Ames, USA.

Al-Habeeb, M.A., Mohamed M.H. and Sharawi S. 2013. Detection and characterization of Newcastle disease virus in clinical samples using real time RT-PCR and melting curve analysis based on matrix and fusion genes amplification. Veterinary World 6(5), 239-243.

Ashraf, A. and Shah, M.S. 2014. Newcastle disease: present status and future challenges for developing countries. African J. of Microb. Res. 8(5), 411-416.

Brown, C., King, D.J. and Seal, B.S. 1999. Pathogenesis of Newcastle disease in chickens experimentally infected with viruses of different virulence. Vet. Pathol. 36, 125-132.

Calnek, B.W., Barnes, H.T., Beared, W., McDougald, L.R. and Saig, Y.M. 1997. Poultry Dis- 
eases $\mathrm{m} 4^{\text {th }}$ Ed. lowa State University Press, Ames, lowa, U.S.A, pp. 496-519.

Coakes, S.J., Steed, L. and Dzidic, P. 2006. Statistical Package for Social Sciences (SPSS) Version 130 for Windows: Analysis without Anguish. Milton: John Wiley \& Sons.

Dortmans, J.C., Peeters, B.P. and Koch, G. 2012. Newcastle disease virus outbreaks: vaccine mismatch or inadequate application. Vet. Microbiol. 160, 17-22.

El-Masry, Samar S., Othman B.A. and ElDougdoud, K.A. 2016. Isolation and identification of Some Strains of Avian Paramyxovirus-1 from Poultry Birds, Ph.D. Thesis of Agric. Sc. (Agricultural viruses), Fac. of Agriculture, Ain shams Univ., Cairo, Egypt, pp. 95115.

Grimes, S.E. 2002. A basic laboratory manual for the small-scale production and testing of $\mathrm{I}-2$ Newcastle disease vaccine. In FAO Regional Office for Asia and the Pacific publication, Bangkok, Thailand Senior Animal Production and Health Officer and Secretary of APHCA and FAO Regional Office for Asia and the Pacific (RAP), Thailand, 139 p.

Hamal, K.R., Burgess, S.C., Pevzner, I.Y. and Erf, G.F. 2006. Maternal antibody transfer from dams to their egg yolks, egg whites, and chicks in meat lines of chickens. Poultry Sci., 85, 1364-1372.

Jayawardane, G.W.L. and Spradbrow, P.B. 1995. Mucosal immunity in chickens vaccinated with the V4 strain of Newcastle disease virus. Vet. Microbiol., 46, 69-77.

Jensensius, J.C., Anderson, I., Han, J. Crone, M. and Koch, C. 1981. Eggs conveniently packaged antibodies. Methods for purification of yolk IgG. J. Immunol. Methods 46, 63-68.

Manzoor, R. 1999. Effective of Angovac (oil based killed HPS virus vaccine) against HPS in broilers. M.Sc. Thesis, College of veterinary Sciencem Lahore, Pakistani, pp. 115-118.

Murphy, F.P., Gibbs, E.P., Horzinek, M.C. and Studdert, M.J. 1999. Paramyxoviridae. Veterinary Virology, $3^{\text {rd }}$ Ed., Academic Press, USA, pp. 412-128

Nchimuthu, K., Jayaraman, M.S. and Balaprakasam, R.A. 1982. Comparison of CDF-66. LaSota strain of Newcastle disease virus vaccine with reference to route of inoculation in chicks. Poult. Abst., 9(3), 664-672.
OIE (Office Internatioal des Epizooties), 2012. Manual of diagnostic tests and vaccines for terrestrial animals: mammals, birds and bees. Biological Standards Commission. World Organization for Animal Health, Paris. pp.1-19

Rehmani, S.F. 1996. Newcastle disease vaccination: A comparison of vaccines and routes of administration in Pakistan. Prev Vet. Med. 25(3), 241- 248.

Reed, L.J. and Muench, H. 1938. A simple method for estimating fifty percent end points. Am. J. Hyg., 27,493-497.

Roy, P., Koteeswaran, A., Sridevi, P. and Venugopalan, A. 1998. Comparison of Newcastle disease vaccines by serology using serum, tears and feather pulp samples. Trop Anim HIth Prod. 30(1), 31-35.

Senne, D.A., King, D.J. and Kapczynski, D.R. 2004. Control of Newcastle disease by vaccination. Dev. Biol. (Basel), 119165- 119170.

Shabbir, M.Z., Zohari, S., Yaqub, T., Nazir , J., Shabbir M.A., Mukhtar N., Shafee, M., Sajid, M., Anees, M., Abbas, M., Khan, M.T., Ali, A.A., Ghafoor, A., Ahad, A., Channa, A.A., Anjum, A.A., Hussain, N., Ahmad, A., Goraya, M.U., Iqbal, Z., Khan, S.A., Aslam, H., Zehra, K., Sohail, M.U., Yaqub, W., Ahmad, N., Berg, M. and Munir, M. 2013. Genetic diversity of Newcastle disease virus in Pakistan: a countrywide perspective. Virol. J. 10, 170180.

Stones, P.B. 1979. Self-infection of veterinary oilemulsion vaccines. British Medical Journal, 1:126. Synder, D.B., Marquardt, W.W., Mallinson, Russe, K., Cohen, E.T.E., Savage, P.K. and Allan, D.C. 1986. Rapid serological profiling by enzyme-linked Immunosorbant assay. IV Association of infectious bursal disease serology with broiler flock performance. Avian Diseases, 30, 139-148.

Sun, B., Qiyn, G. and Caihang, W. 1997.Immune response of conjunctive of Newcastle disease virus in chicks. Veternaria et zootechnica Suinica. 28 (5), 245-250.

Tizzard, I.R. 1996. Veterinary Immunology; W.B. Saunders Company, A division of Harcourt brace and company Asia. PTE limited, $5^{\text {th }}$ Ed. pp. 251-263.

Winterfield, R.W. 1969. immunity response to the infectious bursal disease. Avian Diseases 13, 548-557. 

دراسة مقارنة لطرق مختلفة من التحصين ضد مرض النيوكاسل فى الاجاج البياض

[21]

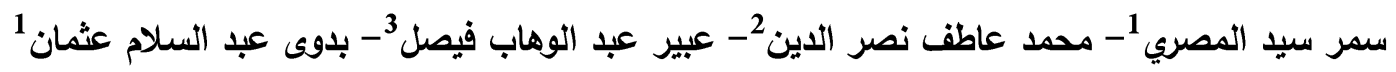
1. 2. 3. ق قسم أساسيات العلوم الززاعية التطبيقية- معهد التعاون الزراعى- القاهرة- مصر .

*Corresponding author: samar_sayed@agr.asu.edu.eg

Received 24 February, 2019, Accepted 9 April, 2019

مقارنة بالمجاميع غير المحصنة، كما أوضحت النتائج

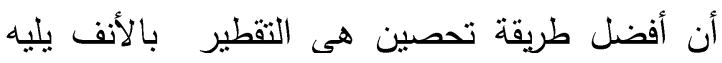

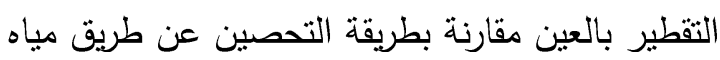

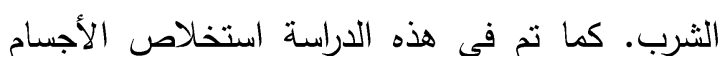

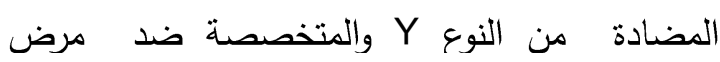

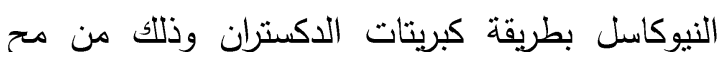

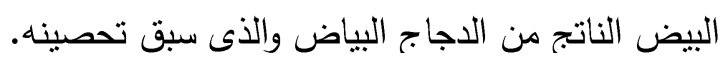

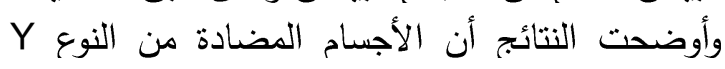

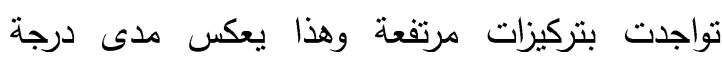

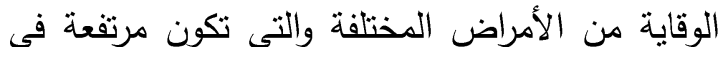

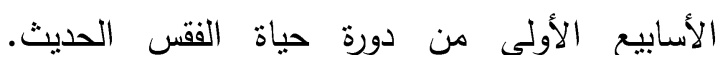

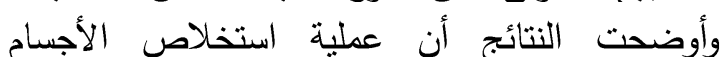

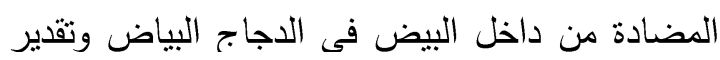
تركيزها سوف يساهم كثيرا فى تحديد برنامج التحصين التياضي وتئن

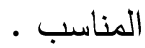

الكلمات الدالة: طرق التحصين، مرض النيوكاسل،

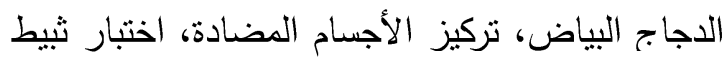
تجمع الهيم، تكنيك الإليزا.

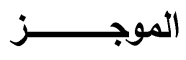

فى هذه الدراسة تم محاولة تقدير مستويات الأجسام

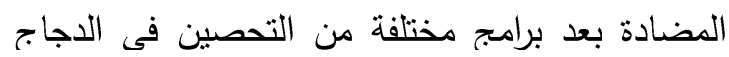
البياض ضد مرض النيوكاسل. تم تقسيم عدد 200

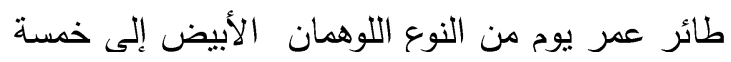

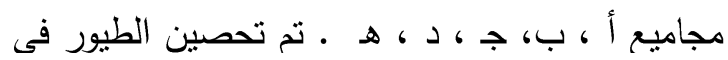

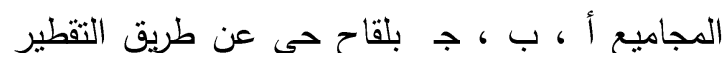

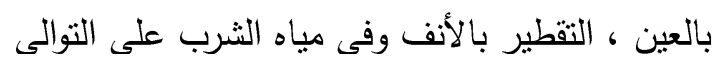
بينما تركت المجاميع د \& ه هـ بدون تحصين الأفين كمقارنة.

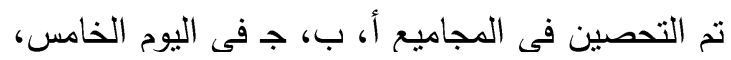

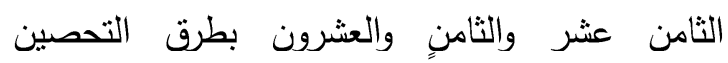

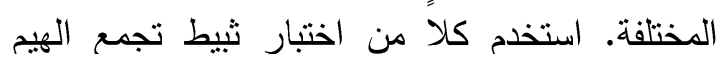

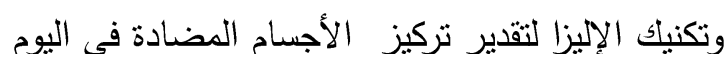

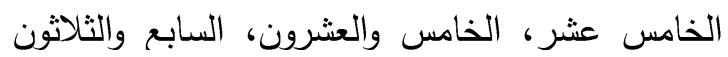

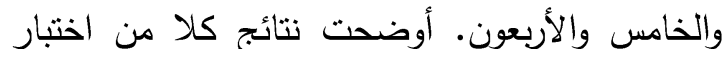
ثيط تجمع الهيم و تكنيك الإليزا تسجيل فروق التئ معنوية بداية من اليوم الخامس والعشرون في تقدير ت تركيز

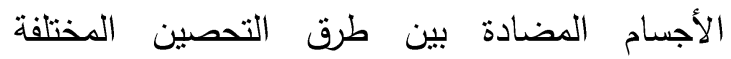

